\title{
APOSTERIORI DISKURSUS IMPLEMENTASI KURIKULUM 2013 \& KTSP \\ (ANALISIS PENERAPAN PADA LEMBAGA PENDIDIKAN SLTA DI LINGKUNGAN PONDOK PESANTREN NURUL JADID)
}

\author{
Hambali $^{1 *}$, Sumyani ${ }^{1}$ \\ ${ }^{1}$ Universitas Nurul Jadid \\ Email:*hambali.amien@gmail.com
}

Website: https://jurnal.uin-antasari.ac.id/index.php/itjik/index

Received: 8 November 2019; Accepted: 15 Desember 2019; Published: 16 Desember 2019

\begin{abstract}
The 2013 curriculum currently uses a scientific approach to give students the breadth of learning, because students do not have to get information only from the teacher. This research gave birth to several learning experiences for both teachers and students as well as exchange of ideas related to the 2013 curriculum and educational unit level curriculum. The objectives of this paper are: (1) to explain the concept of 2013 curriculum learning and KTSP; (2) to present the answers from the results of research on the implementation of the 2013 curriculum at high school educational institutions in the Nurul Jadid Islamic Boarding School neighborhood. The results of the research show that based on observations and interviews, researchers found the answer that high school educational institutions in Nurul Jadid Islamic Boarding Schools have implemented the 2013 curriculum well. Where the school and teachers strive for the success of the 2013 curriculum. In the learning process the teacher has used a scientific approach. Where in these activities students have played a more active role than the teacher. But there are still some subjects that do not use the scientific approach, because of the difficulty of these subjects if using a scientific approach.
\end{abstract}

Key Words: aposteriori; 2013 curriculum implementation; K13 discourse \& KTSP

\begin{abstract}
ABSTRAK
Kurikulum 2013 yang hadir saat ini menggunakan pendekatan saintifik guna memberikan keluasan kepada siswa dalam proses pembelajaran, karena siswa tidak harus mendapatkan informasi hanya dari guru. Penelitian ini melahirkan beberapa pengalaman belajar baik bagi guru maupun siswa serta pertukaran ide terkait kurikulum 2013 dan kurikulum tingkat satuan pendidikan. Tujuan dari penulisan ini adalah: (1) untuk menjelaskan konsep pembelajaran kurikulum 2013 dan KTSP. (2) Untuk memaparkan jawaban dari hasil penelitian tentang pelaksanaan kurikulum 2013 pada lembaga pendidikan SLTA di lingkungan Pondok Pesantren Nurul Jadid. Kesimpulan dari hasil penelitian bahwa berdasarkan observasi dan wawancara, peneliti menemukan jawaban bahwasanya pondok pesantern Nurul Jadid khususnya lembaga pendidikan SLTA telah menerapkan kurikulum 2013 dengan baik. Pihak sekolah dan guru berupaya untuk keberhasilan kurikulum 2013 tersebut. Dalam kegiatan belajar mengajar di kelas guru sudah menggunakan pendekatan saintifik. Dimana dalam kegiatan tersebut yang berperan aktif adalah siswa bukan guru. Tetapi masih ada beberapa mata pelajaran yang tidak menggunakan pendekatan saintifik, dikarenakan sulitnya mata pelajaran tersebut jika menggunakan pendekatan saintifik.
\end{abstract}

Kata Kunci: aposteriori; implementasi kurikulum 2013; diskursus K13 \& KTSP 


\section{PENDAHULUAN}

Indonesia, sejak kemerdekaan 1945 sudah mengalami sebelas kali perubahan kurikulum. Kesesuaian antara kurikulum pendidikan dengan kemajuan ilmu pengetahuan, teknologi, dan masyarakat merupakan salah satu tujuan pendidikan. Namun, setiap kali negeri ini melakukan perubahan kurikulum akan muncul tanggapan setuju dan tidak (Syarwan, 2014).

Perbaikan kurikulum menjadi suatu keharusan yang mesti dilakukan untuk menyempurnakan kurikulum tersebut sesuai dengan tuntutan zaman. Meningkatkan mutu pendidikan dengan melihat kebutuhan masyarakat dan peserta harus terus menerus dilakukan oleh suatu kurikulum, agar tingkat kriminalitas yang sering terjadi pada anak bangsa yang tergolong masih remaja bisa diminimalisir (Supriyono, 2015). Fakta dan anggapan masyarakat tentang menurunnya kualitas sikap dan moral anak-anak atau moral generasi, juga banyak sekali siswa yang tidak memahami fungsi dan tanggung jawabnya sebagai peserta didik membuat Indonesia diharuskan merubah kurikulum yang mengedepankan pendidikan berbasis karakter yang bertujuan untuk membangun karakter anak bangsa. (Yetty Morelent dan. Syofiani, 2015).

Pada tahun 2013, Pemerintah mengeluarkan Permendikbud Nomor 65 tentang perlunya diadakan perubahan Standar Proses, serta sistem pembelajaran dan sistem penilaian sebagai implikasi dari perubahan pada standar proses tersebut. Kurikulum 2013 yang dikembangkan saat ini, sangat berkaitan dengan kurikulum yang sebelumnya, yaitu KTSP. Seluruh sekolah di Indonesia sudah menerapkan KTSP sejak tahun 2006 yang menggunakan pendekatan terpusat pada bidang studi (subject-centered curriculum). Karakteristik KTSP adalah memilah struktur kurikulum ke dalam berbagai mata pelajaran yang dipandang sangat perlu bagi peserta didik. Akan tetapi, saat ini pemerintah memandang kurikulum tersebut kurang mampu memenuhi kompetensi yang dibutuhkan masa kini yang disebut sebagai abad ilmu pengetahuan dan knowledge-based society (Mastur, 2017).

Millenium ketiga merupakan tonggak bagi bangsa-bangsa diseluruh dunia untuk melakukan perubahan dalam berbagai aspek kehidupan. Para pemimpin dunia telah sepakat dengan adanya "Deklarasi Milenium" yang berisi keinginan untuk memberantas kemiskinan agar manusia bisa hidup sejahtera. Sejalan dengan komitmen tersebut, dalam memasuki milenium baru, bangsa Indonesia benar-benar memasuki sebuah era baru yang dalam banyak hal sangat fundamental. Pada zaman milenial ini, pendidikan yang diharapkan di Indonesia adalah secara sadar menyiapkan peserta didikan dengan kegiatan dan pengajaran yang disesuaikan dengan tantangan zaman. Juga ada hal yang sangat urgen dalam pendidikan yaitu proses pembelajaran yang kontekstual akan menjadikan pembelajaran bermakna karena mengaitkan kehidupan nyata dengan konteks lingkungan pribadi, sosial, dan budaya (Lalo, 2018). Bangsa Indonesia untuk menyiapkan lulusan/generasi yang produktif, kreatif, inovatif dan afektif melakukan kebijakan perubahan kurikulum 2013 yang melalui banyak tantangan internal maupun eksternal (Machali, 2014).

Pesantren merupakan lembaga pendidikan tradisional yang tumbuh dengan baik dalam kehidupan masyarakat muslim dan ikut terlibat dalam upaya menekankan pentingnya moral keagamaan serta mencerdaskan kehidupan bangsa. Pesantren juga telah memberikan kontribusi yag cukup signifikan dalam penyelenggaraan pendidikan di Indonesia (Nizar, 2013). Dalam bidang lembaga pendidikan, Pesantren Nurul Jadid menerapkan sistem yang sistematis dan terencana. Sehingga, output yang dihasilkan mempunyai kemampuan dan kompetensi dalam berbagai bidang, untuk dijadikan persiapan dalam mengabdi, baik 
bagi diri sendiri, agama atau tanah air. Peningkatan kinerja terus digalakkan oleh Pondok Pesantren Nurul Jadid khususnya Biro Pendidikan sebagai lembaga yang berperan aktif dalam pengembangan pendidikan. Lembaga pendidikan yang ada di Pondok Pesantren Nurul Jadid meliputi tingkat dasar hingga tingkat perguruan tinggi.

$\begin{array}{lr}\text { Kementrian } & \begin{array}{c}\text { Pendidikan dan } \\ \text { Kebudayaan }\end{array}\end{array}$
menyampaikan serta menegaskan bahwa kurikulum 2013 harus dilaksanakan pada setiap sekolah tahun 2018/2019. Dirjen mengharapkan bahwa diakhir tahun 2018/2019 merupakan terakhir pelatihan dan pendampingan terkait proses pembelajaran kurikulum 2013.

Melihat hasil penelitian dari Soler, Quiles, \& Hargreaves terhadap 13 program Pendidikan musik Kolombia untuk dijadikan inspirasi guna memberikan pelatihan kepada guru. Hasil penelitian tersebut menunjukkan, bahwa kebaruan relatif dari program kurikulum merupakan faktor kunci keberhasilan suatu penelitian. Dengan adanya pembaharuan kurikulum 2013 memerlukan pemahaman secara komprehensif bagi kepentingan pelaksana kurikulum, seperti guru, kepala sekolah, pengawas, dan penjaminan mutu pendidikan di lapangan (Sutjipto, 2016).

Sebab itu, lembaga pendidikan dibawah yayasan Pondok Pesantren Nurul Jadid juga harus menerapkan kurikulum 2013. Biro Pendidikan Pondok Pesantren Nurul Jadid mengadakan pelatihan terkait kurikulum yang baru. Seseorang paling tidak memilki tiga pengalaman jika sudah terlibat aktif pada pelatihan terkait kurikulum 2013, yaitu: 1) pemahaman terhadap ide dan desain kurikulum, 2) strategi penyajian implementasi kurikulum, dan 3) menyampaikan konsep kurikulum (Kemdikbud, 2016a) (Sutjipto, 2016).

Berdasarkan deskripsi tersebut, peneliti tertarik untuk melaksanakan penelitian apakah implementasi kurikulum 2013 yang ditegaskan oleh Kemendikbud sudah benar-benar diterapkan dengan baik di lembaga pendidikan SLTA di Pondok Pesantren Nurul Jadid. Alasan peneliti melaksanakan penelitian ini karena peneliti ingin menemukan jawaban melalui pengalaman dan pertukaran ide terkait dengan implementasi kurikulum antara kurikulum 2013 dan KTSP 2006, apakah perintah Kementrian dan Kebudayaan agar lembaga pendidikan dasar menengah (DASMEN) telah menerapkan dengan baik kurikulum 2013 tersebut.

\section{PEMBAHASAN}

a. Pengertian Kurikulum 2013

Dalam dunia pendidikan, kurikulum bukanlah istilah yang asing lagi. Kurikulum dalam arti tradisional dikenal sebagai mata pelajaran, bahkan hingga tahun-tahun pertama pada abad dua puluh, kebanyakan para pendidik menganggap kurikulum sebagai kumpulan mata pelajaran. Kurikulum yang disebut sebagai mata pelajaran merupakan pemahaman yang menghubungkan kurikulum dengan daftar mata pelajaran yang diajarkan. Misalnya, ketika siswa sedang belajar mata pelajaran IPA, maka pada dasarnya siswa tersebut sedang mempelajari ilmu pengetahuan alam. Kurikulum dalam arti tradisonal ini, biasanya dikaitkan dengan memperoleh ijazah. Ijazah sendiri digambarkan dengan laporan kemampuan peserta didik. Artinya, apabila peserta didik sudah memahami dan menguasai materi, dia pasti akan memperoleh ijazah. Kemampuan tersebut bisa dilihat dari nilai mata pelajaran yang tertulis dalam ijazah. Begitupun sebaliknya, apabila siswa memiliki nilai yang belum memenuhi standar tertentu, berarti siswa tersebut belum memiliki kemampuan atau tidak akan mendapatkan ijazah. Untuk melihat apakah siswa telah menguasai atau tidaknya suatu mata pelajaran bisa dilihat dengan cara evaluasi hasil belajar. Sasaran akhir dari konsep kurikulum tersebut dengan menguasai isi pelajaran (Sanjaya, 2008a). 
Tarbiyah: Jurnal Ilmiah Kependidikan

Vol. 8 No. 2 Juli - Desember 2019 (101-116)

Selain dimaknai sebagai sekumpulan mata pelajaran, kurikulum dapat pula diartikan sebagai serangkaian pengalaman belajar peserta didik, dalam hal ini juga berlaku perubahan ruang lingkup, yakni dari konsep yang sempit menjadi lebih luas. Seperti yang dikemukakan oleh Doll berikut: Sekolah memiliki tanggung jawab untuk memberikan pengalaman kepada peserta didik. Guru harus mempunyai upaya agar peserta didik terdorong untuk melakukan sebuah pengalaman yang berkenaan dengan pelajaran atau tidak, pengalaman tersebut bisa didapatkan disekolah, di rumah, atau di masyarakat, bersama guru atau tanpa guru (Widyastono, 2015).

Hilda Taba sebagaimana dikutip Sanjaya, menyebutkan: Kurikulum merupakan perencanaan pembelajaran yang memuat berbagai petunjuk belajar serta hasil yang diharapkan (Fadlillah, 2014). Dalam konsep kurikulum tersebut, Daniel Tanner dan Laurel Tanner menyatakan petunjuk belajar serta hasil yang diharapkan harus direncanakan dan diarahkan oleh sekolah demi memberikan pengalaman kepada siswa (Sanjaya, 2008).

Menurut Zainal Arifin, Daniel Tanner \& Laurel Tanner berpendapat bahwa kurikulum adalah pengalaman pembelajaran yang terencana dan terarah, yang disusun melalui proses rekontruksi pengetahuan dan beberapa pengalaman yang sistematis supaya anak didik terus memiliki minat untuk belajar di lembaga sekolah (Baharun, 2017). Menurut Reksoadmojo, kurikulum adalah merupakan beberapa rencana dan pengaturan sebagai pedoman dalam menyelenggarakan kegiatan pembelajaran mengenai bahan, isi, dan tujuan pelajaran untuk mencapai tujuan pendidikan (Sufairoh, 2016).

Arah dari revitalisasi dan perbaikan kurikulum adalah sebagai perbaikan sistem pendidikan yang dirasa kurang sesuai dengan yang diinginkan. Usaha perbaikan tersebut dilakukan demi terciptanya generasi masa depan yang berkarakter, memahami jati diri bangsa, menciptakan dan mewujudkan anak yang unggul, yang bisa bersaing di dunia internasional (Baharun, 2017).

Kurikulum 2013 merupakan suatu kebijakan baru pemerintah dalam bidang pendidikan agar bangsa Indonesia mampu menjawab tantangan dan persoalan yang akan dihadapi masa depan. Perubahan pada kurikulum 2013 yang paling dasar daripada kurikulum-kurikulum sebelumnya adalah perubahan pada tingkat satuan pendidikannya yang mana implementasi kurikulum 2013 ini dilakukan pada tingkat satuan pendidikan mulai dari sekolah dasar (SD), sekolah menengah pertama (SMP), dan sekolah menengah atas (SMA) atau sekolah menegah kejuruan (SMK). Perubahan yang lain dari kurikulum 2013 yaitu berkurangnya sejumlah mata pelajaran pada jenjang pendidikan SD dan SMP, serta hilangnya sistem penjurusan pada sekolah tingkat atas atau SMA. Perubahan yang lain dapat dapat dilihat dari konsep kurikulum 2013 itu sendiri (Alinawati, 2013).

Sebelum melaksanakan kurikulum 2013, harus disadari terlebih dahulu, bahwa kurikulum 2013 sarat akan pendidikan karakter. Dalam kurikulum 2013 akan menyita waktu pendidik untuk mengumpulkan nilai satu persatu dari peserta didik di setiap mata pelajaran, karena dalam kurikulum 2013 penilaian tidak berbentuk angka tetapi berbentuk uraian (kualitatif), hal ini akan sangat membebani pendidik, jika pendidik tidak memahami landasan pemikiran bahwa kurikulum 2013 adalah sangat memperhatikan pendidikan karakter (Zaini, 2013).

Pendidikan karakter merupakan usaha sadar manusia yang memiliki watak dan kepribadian yang baik, berakhlak yang baik, selalu positif kepada alam dan masyarakat dengan mengembangkan potensi melalui pembelajaran di lingkungan sekolah. Dalam kurikulum 2013, pendidikan karakter dilakukan melalui integrasi capaian pembelajaran, 
guru memberikan teladan yang baik serta berkompeten, dan membangun peran lembaga pendidikan (Islam, 2017).

b. Pengembangan Kurikulum 2013

$$
\text { Dalam bahasa Inggris, }
$$
pengembangan adalah development yang diambil dari kata develop artinya tumbuh, bertambah, menjadi lebih besar atau lebih lengkap. Wina Sanjaya menyebutkan bahwa pengembangan mempunyai dua makna. Pertama, pengembangan adalah suatu kegiatan yang menghasilkan hal baru (construction). Kedua, pengembangan adalah menyempurnakan hal yang sudah ada (improvement) (Alamsyah, 2013).

Pengembangan kurikulum adalah sebuah proses yang merencanakan, mewujudkan sesuatu agar lebih baik dengan melakukan evaluasi dari kurikulum sebelumnya, sehingga menciptakan kondisi pembelajaran yang lebih baik. Dengan kata lain, pengembangan kurikulum adalah suatu kegiatan yang dilaksanakan dengan melalui tahap-tahap penyusunan kurikulum yang didasarkan dengan hasil evaluasi yang dilakukan demi menghasilkan kurikulum yang baru yang lebih baik (Mastur, 2017).

Pengembangan kurikulum mempunyai beberapa pendekatan, yaitu: Pendekatan kompetensi, pendekatan sistem, pendekatan klarifikasi nilai, pendekatan komprehensif, pendekatan yang fokus pada masalah, dan pendekatan terpadu. Pendekatan kompetensi adalah keterpaduan antara ranah kognitif (pengetahuan), afektif (sikap) dan psikomotor (keterampilan). Pendekatan kompetensi mempunyai ciri berpikir dengan teratur, penilaian difokuskan pada tingkat kemampuan, serta dapat memperbarui diri. Pendekatan sistem adalah suatu sistem yang berupa proses. Proses tersebut adalah untuk merumuskan masalah, mengidentifikasi strategi pemecahan masalah, dan evaluasi. Pendekatan klarifikasi nilai adalah menekankan peserta didik agar mengemukakan pendapatnya sendiri disamping pendapat guru mengenai sebuah konflik. Pendekatan komprehensif adalah mengidentifikasi masalah yang bersifat umum yang ada dalam kurikulum dengan melalui beberapa langkah guna mencapai sasaran. Pendekatan yang berpusat pada mengidentifikasi masalah kurikulum yang bersifat khusus melalui langkah mencari informasi tentang masalah, keinginan, dan kesulitan yang dihadapi dalam pembelajaran. Pendekatan terpadu adalah memadukan seluruh bagian dan indikatorindikator untuk mencapai satu tujuan tertentu (Arifin, 2013).

Kurikulum 2013 menitikberatkan agar siswa mampu dalam melakukan penelitian/observasi, bertanya (wawancara), mencoba, bernalar serta mengkomunikasikan (mempersentasikan) materi yang mereka dapatkan setelah menerima mata pelajaran. Berubahnya kurikulum KTSP ke kurikulum 2013 merupakan upaya untuk mengantisipasi masa depan dan menyiapkan generasi yang mampu dan siap dalam menghadapi tantangan masa depan (Supriyono, 2015). Seorang guru diharuskan merubah pola pikirnya agar terus mengikuti perubahan zaman dalam dunia pendidikan, yang awalnya awam dan kaku, kini berubah menjadi lebih modern (Otang Kurniawan, 2017).

Sistem merupakan satu kesatuan komponen yang saling berkaitan satu sama lain untuk mencapai satu tujuan tertentu. Ada tiga ciri dari suatu sistem, yaitu: memiliki sasaran/tujuan tertentu; suatu sistem mempunyai fungsi untuk mencapai tujuan dengan didukung berbagai komponen.

Sistem pembelajaran adalah gabungan dari beberapa unsur yang terdiri dari unsur manusiawi, fasilitas, material, perlengkapan dan prosedur untuk mencapai satu tujuan. Dalam sistem pembelajaran, unsur manusiawi terdiri dari siswa, guru, serta orang-orang yang terlibat dan mendukung terhadap keberhasilan proses pembelajaran. Material adalah beberapa bahan pembelajaran yang dijadikan sumber belajar, seperti buku- 
buku, slide suara, film, foto, dan lain sebagainya. Fasilitas dan perlengkapan adalah segala sesuatu yang dapat memudahkan dan melancarkan proses pembelajaran, misalnya ruang kelas dan peralatan didalam kelas, perlengkapan komputer, audio-visual dan sebagainya. Prosedur adalah rentetan beberapa kegiatan dalam proses pembelajaran, misalnya jadwal, metode dan strategi pembelajaran, evaluasi dan sebagainya. Jadi tujuan utama dalam sistem pembelajaran yaitu keberhasilan siswa dalam mencapai tujuan.

Dari uraian diatas dapat disimpulan bahwa tugas seorang desainer pembelajaran meliputi tiga hal pokok, yaitu: Pertama, sebagai perencana, yakni mengorganisasikan semua unsur yang ada agar berjalan dengan baik, sebab jika salah satu dari unsur tersebut tidak berjalan dengan baik maka akan merusak sistem tersebut. Kedua, pengelola implementasi dengan jadwal dan prosedur yang telah direncanakan. Ketiga, untuk menentukan efetivitas, efisiensi sistem pembelajaran diadakan evaluasi terkait keberhasilan siswa (Sanjaya, 2008b).

Dalam kurikulum 2013 terdapat perbedaan karakteristik dengan KTSP, yaitu: pendekatan pembelajaran, kompetensi lulusan, dan penilaian.

Pendekatan dalam kurikulum 2013 menggunakan pendekatan saintifik (ilmiah) dan tematik-integratif. Pendekatan saintifik adalah pendekatan pembelajaran yang dimulai dari proses mengamati (observing), menanya (questioning), mencoba (experimenting), menalar (associating), dan mengomunikasikan (communicating). Pendekatan saintifik ini dimaksudkan memberikan pemahaman kepada peserta didik bahwasanya informasi bisa berasal darimana saja, kapan saja, tidak tergantung kepada informasi dari guru. Melalui observasi, siswa didorong untuk mencari tahu berbagai sumber yang sesuai dengan isi pembelajaran (Syofiani, 2015). Kriteria dalam pendekatan ilmiah yaitu lebih mengedepankan penalaran induktif (inductive reasoning) daripada penalaran deduktif (deductive reasoning). Penalaran induktif yaitu melihat fenomena yang umum dan kemudian mencari kesimpulan yang khusus (spesifik). Sebaliknya, penalaran deduktif yaitu melihat fenomena yang khusus dan ditarik kesimpulan yang umum (Waseso, 2018).

Pendekatan saintifik merangsang kemampuan berfikir tinggi dengan melalui proses kognitif, yaitu menekankan kepada proses keterlibatan peserta didik atau siswa yang berorientasikan pada pengalaman belajar langsung serta mendorong agar siswa menemukan dan mengaitkan hubungan antara pengalaman belajar dengan fakta. Dalam pendekatan saintifik, siswa tidak hanya diharapkan memahami tema yang dipelajari tetapi diharapkan dapat diterapkan dalam kehidupan seharihari (Yoserizal Bermawi, 2016).

Dalam kegiatan pembelajaran kurikulum 2013, pendekatan saintifik dapat dilakukan dengan cara berikut.

Tabel 1. Kegiatan Pembelajaran Kurikulum 2013

\begin{tabular}{|c|c|}
\hline KEGIATAN & $\begin{array}{c}\text { AKTIVASI } \\
\text { PEMBELAJARAN }\end{array}$ \\
\hline $\begin{array}{l}\text { Mengamati } \\
\text { (observing) }\end{array}$ & $\begin{array}{l}\text { Melihat, mengamati, } \\
\text { membaca, mendengar, } \\
\text { menyimak (tanpa dan } \\
\text { dengan alat) }\end{array}$ \\
\hline $\begin{array}{l}\text { Menanya } \\
\text { (questioning) }\end{array}$ & $\begin{array}{l}\text { - Mengajukan } \\
\text { pertanyaan dari yang } \\
\text { hal yang nyata sampai } \\
\text { ke yang bersifat } \\
\text { jawaban sementara. } \\
\text { - Membiasakan } \\
\text { kemandirian dengan } \\
\text { diawali bimbingan } \\
\text { guru. }\end{array}$ \\
\hline $\begin{array}{l}\text { Mencoba } \\
\text { (experimenting) }\end{array}$ & $\begin{array}{l}\text { Menentukan sumber } \\
\text { referensi yang } \\
\text { didapatkan dari buku, } \\
\text { benda, atau dokumen } \\
\text { untuk menjawab } \\
\text { beberapa pertanyaan } \\
\text { - Mengumpulkan data. }\end{array}$ \\
\hline $\begin{array}{l}\text { Menalar } \\
\text { (associating) }\end{array}$ & $\begin{array}{lr}\text { - } & \text { Menganalisis } \\
\text { menarik kesimpulan } \\
\text { hubungan antara } \\
\text { sumber referensi } \\
\text { dengan hasil }\end{array}$ \\
\hline
\end{tabular}




\begin{tabular}{ll}
\hline & $\begin{array}{l}\text { Dimulai dari } \\
\text { unstructured-uni } \\
\text { structure- } \\
\text { multistructure- } \\
\text { complicated structure. }\end{array}$ \\
Mengomunikasikan & $\begin{array}{l}\text { Menyampaikan hasil } \\
\text { (communicating) } \\
\text { konseptualisasi. } \\
\text { Dalam bentuk ucapan, } \\
\text { penulisan, gambar, } \\
\text { atau media lainnya. }\end{array}$ \\
\hline
\end{tabular}

Sementara pendekatan tematikintegratif dalam pembelajaran kurikulum 2013 dibuat pertema dengan tetap mengacu pada karakteristik peserta didik yang dilaksanakan dengan integrasi antara satu mata pelajaran dengan mata pelajaran yang lain. Untuk dapat mengintegrasikan mata pelajaran yang diampu dengan mata pelajaran yang diampu orang lain, seorang guru dituntut untuk lebih kreatif. Agar menghasilkan peserta didik yang memiliki sikap, keterampilan, dan multipengetahuan yang memadai untuk menghadapai berbagai rintangan dimasa depan dengan menyeimbangkan atau memadukan kekreatifan seorang guru dalam setiap mata pelajaran.

Kurikulum 2013 juga disusun dengan mengembangkan dan menguatkan kompetensi sikap, pengetahuan, dan keterampilan peserta didik secara seimbang. Artinya, melalui pemahaman dan pengetahuan yang telah didapat, siswa dapat mempraktikkan sikap spiritual dan sosial dengan menumbuhkan budaya keagamaan (religious culture) disekolah. Hal ini menyesuaikan dengan karakteristik Pendidikan Agama Islam dan sesuai dengan tujuan pendidikan nasional, yaitu untuk mengembangkan potensi peserta didik agar menjadi manusia yang bisa bermanfaat untuk diri sendiri, masyarakat, dan negeri (Machali, 2014). Titik tekan dalam kurikulum 2013 berbeda dengan kurikulum Tingkat Satuan Pendidikan (KTSP). Dalam KTSP yang lebih diutamakan adalah kemampuan pengetahuan (kognitif), sedangkan dalam kurikulum 2013 yang diutamakan adalah kemampuan sikap (afektif).
Ketiga ranah tersebut akan diperoleh (proses perolehan) yang berbeda. Sesuai dengan tabel berikut.

Tabel 2. Proses Perolehan Materi

\begin{tabular}{|cl|}
\hline Domain & \multicolumn{1}{c|}{ SD SMP SMA/K } \\
\hline & $\begin{array}{l}\text { Menerima - menjalankan - } \\
\text { menghargai - menghayati - } \\
\text { mengamalkan. }\end{array}$ \\
\cline { 2 - 3 } Sikap & $\begin{array}{l}\text { Pribadi yang beriman, } \\
\text { berakhlak mulia, percaya diri, } \\
\text { dan bertanggung jawab dalam } \\
\text { berinteraksi secara efektif } \\
\text { dengan lingkungan sosial, } \\
\text { alam sekitar, serta dunia dan }\end{array}$ \\
peradabannya. \\
\hline Mengingat - memahami - \\
menerapkan - menganalisis - \\
mengevaluasi \\
\hline $\begin{array}{l}\text { Pribadi yang dapat menguasai } \\
\text { ilmu pengetahuan, teknologi, } \\
\text { seni, budaya, dan berwawasan } \\
\text { kemanusiaan, kebangsaan, } \\
\text { kenegaraan, dan peradaban }\end{array}$ \\
$\begin{array}{l}\text { Mengamati - menanya - } \\
\text { mencoba - menalar - menyaji - } \\
\text { mencipta }\end{array}$ \\
\hline Pribadi yang produktif dan \\
kreatif dalam berpikir dan \\
bertindak
\end{tabular}

Dari tabel di atas, peserta didik diharapkan setelah selesai menempuh pendidikan di tingkat dasar ataupun menengah mempunyai kemampuan yang dikuasai. Kemampuan ini yang akan menentukan dimana dan berada dimana saja peserta didik mendapatkan keberhasilan.

Struktur kurikulum adalah komponen mata pelajaran yang harus diselesaikan oleh peserta didik yang didalamnya memuat beban belajar siswa dalam seminggu. Dalam kurikulum 2013 ada perubahan struktur kurikulum dibandingkan dengan kurikulum KTSP. Perubahan tersebut terletak pada bentuk mata pelajaran serta alokasi waktu yang dibebankan kepada peserta didik baik tingkat SD/MI, SMP/MTs, maupun SMA/MA/SMK.

Untuk tingkat SD/MI mata pelajaran yang sebelumnya berjumlah 10 kini diringkas menjadi 7 mata pelajaran, yaitu pendidikan pancasila \& 
kewarganegaraan, matematika, pendidikan agama, bahasa indonesia, pendidikan jasmani, olahraga dan kesehatan, seni budaya dan prakarya, serta pramuka. Khusus untuk pramuka merupakan mata pelajaran wajib yang harus ada di mata pelajaran, dan diatur dalam undangundang. Khusus untuk SD/MI, mata pelajaran IPA dan IPS bersifat tematik integratif, dua mata pelajaran itu sebagai materi pembahasan atau diintegrasikan pada semua mata pelajaran. Pembahasan pelajaran bahasa Indonesia dan matematika diambil dari pelajaran IPA, sedangkan untuk pembahasan materi bahasa Indonesia dan pendidikan pancasila dan kewarganegaraan diambil dari pelajaran IPS. Beban belajar di SD/MI kelas 1 adalah $30 \mathrm{jam} /$ minggu, kelas 2 adalah 32 jam/minggu, dan kelas 3 adalah 34 jam/minggu. Sementara untuk kelas 4 , 5, 6 masing-masing 36 jam setiap minggu. Untuk satu jam pembelajaran pada tingkat SD/MI adalah 35 menit.

Untuk tingkat SMP/MTs, jumlah mata pelajaran ada 10 yang dikelompokkan menjadi 2 bagian, yaitu kelompok A dan B. Mata pelajaran yang menekankan kepada aspek kognitif dan afektif disebut kelompok A. Kelompok B adalah mata pelajaran yang lebih mementingkan aspek afektif dan psikomotor. Kelompok A terdiri dari mata pelajaran pendidikan agama dan budi pekerti, pendidikan kewarganegaraan, bahasa Indonesia, matematika, ilmu pengetahuan alam (IPA), ilmu pengetahuan sosial (IPS) dan bahasa inggris. Kelompok B terdiri dari mata pelajaran seni budaya, pendidikan jasmani, olahraga, dan kesehatan. Beban belajar di SMP/MTs untuk semua kelas mengalami penambahan jumlah jam pembelajaran, yang sebelumnya $32 \mathrm{jam} /$ minggu berubah menjadi 38 jam/minggu. Untuk satu jam pembelajaran adalah 40 menit pada tingkat SMP/MTs.

Untuk tingkat SMA/MA, jumlah mata pelajaran dibagi menjadi dua, yaitu mata pelajaran wajib dan mata pelajaran pilihan (peminatan). Mata pelajaran wajib adalah semua mata pelajaran yang harus diikuti oleh peserta didik disatuan pendidikan, sedangkan mata pelajaran pilihan (peminatan) adalah mata pelajaran pilihan yang diikuti oleh peerta didik sesuai dengan bakat yang disesuaikan dengan kemampuan akademik yang dimilikinya. Beban belajar di SMA/MA untuk kelas X adalah 42 jam belajar, sedangkan untuk kelas XI, dan XII 44 jam belajar. Untuk satu jam pembelajaran pada tingkat SMA/MA adalah 45 menit.

Guru yang mendukung pelaksanaan kurikulum 2013 diharapkan dapat memahami kurikulum 2013 melalui beberapa pelatihan baik itu yang diselenggarakan oleh pemerintah maupun sekolah. Melalui pelatihan tersebut, guru akan lebih mudah menerapkan pembelajaran saintifik dengan sistem penilaian yang bersifat autentik. Sarana dan prasarana seperti LCD juga tak kalah pentingnya dalam keberhasilan pelaksanaan kurikulum 2013 ini. Dengan penyediaan sarana dan prasarana guru tidak akan menemukan kesulitan untuk menciptakan suasana pembelajaran yang berpusat pada siswa (student center), selain itu guru tidak akan menjadi satu-satunya sumber belajar, karena siswa diarahkan untuk mencari bahan materi dengan sarana tersebut (Sumiyatun, 2017).

$\begin{array}{lrr}\text { Pendekatan } & \text { dalam } & \text { penilaian } \\ \text { pembelajaran } & \text { kurikulum } & 2013 \\ \text { menggunakan pendekatan } & \text { penilaian } \\ \text { otentik (authentic assesment). } & \text { Penilaian } \\ \text { otentik adalah penilaian } & \text { secara }\end{array}$ keseluruhan, meliputi kesiapan siswa untuk mengikuti pembelajaran, proses dan hasil belajar. Penilaian ini akan membantu memudahkan para guru dalam mengetahui pencapaian kompetensi peserta didik yaitu sikap, pengetahuan, dan keterampilan. Sebab, dalam 3 kompetensi tersebut memiliki penilaian masing-masing (Fadlillah, 2014).

Kurikulum Tingkat Satuan Pendidikan (KTSP) adalah kurikulum yang disempurnakan dari kurikulum 2004 (KBK). Pendidikan Nasional ini 
mendapatkan permasalahan berupa relevansi atau kesesuaian pendidikan dengan kebutuhan masyarakat. Inilah yang menjadi alasan pemerintah untuk menciptakan KTSP (Sumiyatun, 2017).

Kurikulum tingkat satuan pendidikan adalah kurikulum operasional yang dibuat serta dilaksanakan oleh masing-masing sekolah yang diberlakukan di jenjang pendidikan tingkat dasar dan menengah pada tahun ajaran 2006-2007. Sekolah yang lebih tahu dan paham tentang kondisi satuan pendidikannya, diberikan wewenang untuk mengembangkan dan mengimplementasikan kurikulum sendiri, yakni agar menciptakan sekolah yang efektif, produktif, dan berprestasi (Mulyasa, 2011).

Kurikulum operasional mempunyai makna: Pertama, bersifat operasional, dalam pengembangan kurikulum tersebut tetap mengacu kepada sistem yang ditetapkan oleh pemerintah. Artinya, meskipun sekolah telah diberi wewenang untuk mengembangkan kurikulum, kurikulum tersebut tetap harus mengikuti ketetapan pemerintah. Hal ini untuk mewujudkan tujuan pendidikan nasional yang tertera dalam UU No. 20 Tahun 2003 Pasal 36 ayat 1 tentang sistem pendidikan nasional. Kedua, pengembang kurikulum mempunyai prinsip diversifikasi yang disesuaikan dengan satuan pendidikan, potensi daerah, dan siswa. Ketiga, pengembang kurikulum memilki keleluasaan dalam menetukan hal-hal yang berkaitan dengan pembelajaran (Alamsyah, 2013).

Pengembangan kurikulum dari satu negara mempunyai variasi yang berbeda, tergantung pada nilai-nilai yag dianut masyarakat. Beberapa negara pengembangan kurikulum ditanggungjawabkan pada badan pusat dalam menentukan kurikulum sekolah yang relevan. Ada juga yang memberikan tanggung jawab kepada sekolah-sekolah atau guru-guru, meskipun ada satuan tingkat pendidikan yang masih ada kendali dari pusat melalui penerbitan Standar
Kompetensi Nasional. Beberapa negara bahkan memberikan pengendalian yang besar kepada guru (Alamsyah, 2013).

Ada beberapa hal yang dapat dipahami dari Kurikulum Tingkat Satuan Pendidikan (KTSP) yaitu:

1. Penyusunan kurikulum berpedoman pada BSNP, baik dijenjang pendidikan dasar maupun menengah.

2. KTSP dikembangkan dengan menyesuaikan antara pendidikan, potensi yang dimilki setiap daerah, peserta didik dengan budaya masyarakat disekitarnya.

3. Supervisi Dinas Pendidikan Kabupaten/kota, serta Departemen Agama yang mempunyai tanggung jawab dibidang pendidikan menetapkan kerangka dasar kurikulum dan standar kompetensi lulusan, agar setiap lembaga pendidikan dapat mengembangkan kurikulum dan silabusnya dengan berpedoman kepada penetapan tersebut.

Kurikulum Tingkat Satuan Pendidikan yang dirancang oleh satuan pendidikan bertujuan untuk menjadikan tamatan yang berkompeten dan cerdas agar bertahan hidup dimasa yang akan datang dan siap menghadapi ketidakpastian harapan terhadap dasar-dasar hidup pengetahuan, keterampilan, pengalaman belajar yang bisa membangun hubungan sosial serta mewujudkan karakter nasional dan perubahan tantangan zaman.

Kurikulum tingkat satuan pendidikan (KTSP) sebagai sebuah konsep dan program mempunyai karakteristik berikut:

1. Pemberian otonomi yang luas dan tanggung jawab kepada kepala sekolah untuk menyesuaikan kondisi daerah dengan pendidikan agar dapat mengembangkan kurikulum dengan baik.

2. Adanya dukungan dan partisipasi dari orang tua dan masyarakat untuk melaksanakan kurikulum tersebut. 
3. Pelaksanaan kurikulum didukung oleh partisipasi yang tinggi dari masyarakat dan orang tua peserta didik.

4. Adanya kerjasama dan kekompakan sebuah tim, dan transparan didalam komunikasi tim tersebut.

Dalam KTSP pemerintah menetapkan standar kompetensi dan kompetensi dasar. Standar kompetensi adalah kemampuan-kemampuan pokok yang membentuk kompetensi yang disandarkan untuk tingkat kelas dan semester tertentu. Sekolah dan guru yang diberikan wewenang yang cukup luas dalam pengembangan kurikulum, harus menentukan indikator sendiri dan materi pokok dengan tetap memperhatikan karakteristik KTSP dengan menyesuaikan minat dan situasi daerah peserta didik. Setiap sekolah bisa mengoptimalkan potensinya dengan mengelola dan mengembangkan potensi secara baik, hal ini sangat berkaitan dengan kepala sekolah dan guru yang menjadi peran penting dalam keberhasilan implementasi kurikulum serta gagalnya kurikulum tersebut (Idi, 2014).

Kompetensi dalam KTSP dapat dipetakan sebagai berikut.

Tabel 3. Kompetensi dalam KTSP

\begin{tabular}{ll}
\hline \multicolumn{3}{c}{ KOMPETENSI DALAM KTSP } \\
\hline Kompetensi & $\begin{array}{l}\text { Mewujudkan pengetahuan, } \\
\text { keterampilan, dan sikap } \\
\text { dengan kebiasaan berpikir } \\
\text { dan bertindak. }\end{array}$ \\
$\begin{array}{l}\text { Standar } \\
\text { Kompetensi }\end{array}$ & $\begin{array}{l}\text { Adanya standar kemampuan } \\
\text { ketercapaian untuk tingkat } \\
\text { kelas dan semester. }\end{array}$ \\
$\begin{array}{l}\text { Kompetensi } \\
\text { Dasar }\end{array}$ & $\begin{array}{l}\text { Membentuk kompetensi yang } \\
\text { distandarkan dengan } \\
\text { beberapa kemampuan pokok } \\
\text { peserta didik }\end{array}$ \\
\hline \multicolumn{1}{c}{ Guru diberi keluasan dalam }
\end{tabular}

mengembangkan indikator, materi, kegiatan pembelajaran, dan penilaian untuk dilaksanakan dalam pembelajaran. Guru dalam mengembangkan standar kompetensi dan kompetensi dasar (SKKD) melalui penyusunan silabus dan RPP (rencana pelaksanaan pembelajaran).
Ciri-ciri bahwa siswa telah mencapai kompetensi dasar ditandai dengan indikator. Indikator juga merupakan jabaran kemampuan yang lebih khusus dari kompetensi dasar. Dalam standar isi telah ditentukan bagaimana guru menjabarkan Standar Kompetensi dan Kompetensi Dasar. Hal-hal berikut harus diperhatikan dalam mengembangkan sebuah indikator, yaitu :

1. Menyesuaikan indikator dengan karakteristik peserta didik serta lingkungan sekitar.

2. Menyesuaikan indikator dengan karakteristik mata pelajaran.

3. Menggunakan kata kerja operasional dalam merumuskan Indikator

Dalam mengembangkan pembelajaran, indikator dapat dijadikan sebagai acuan, baik itu acuan dalam mengembangkan pembelajaran maupun acuan dalam penilaian. Indikator dalam mengembangkan pembelajaran berfungsi sebagai tujuan pembelajaran, artinya peserta didik harus menguasai indikator tersebut agar tujuan yang diharapkan bisa tercapai. Indikator yang dijadikan sebagai acuan penilaian adalah siswa dinilai sesuai dengan indikator yang telah dicapai oleh peserta didik.

Untuk menentukan berhasil tidaknya peserta didik dalam mencapai tujuan pembelajaran diperlukan kegiatan penilaian/evaluasi pembelajaran. Dalam kamus Besar Bahasa Indonesia (KBBI), penilaian dapat diartikan sebagai sebuah proses, cara, atau pembuatan nilai. Dalam dunia pendidikan, nilai digunakan untuk mengukur kemampuan peserta didik baik berupa angka maupun deskripsi untuk mengetahui ketercapaian peserta didik dalam mengikuti proses pembelajaran.

Penilaian adalah beberapa kegiatan yang dilakukan secara terencana dan berkesinambungan untuk mendapatkan, menganalisis proses dan hasil peserta didik sehingga menjadi data dalam mengambil keputusan. Dalam konteks ini, guru dapat melakukan penilaian dengan berbagai cara, tetapi harus memperhatikan prinsip-prinsip 
penilaian yang telah ditentukan. Kriteria penilaian meliputi:

1. Penilaian akan mengarahkan kepada ketercapaian indikator serta aspekaspek yang dinilai.

2. Acuan kriteria penilaian berdasarkan apa yang dilakukan peserta didik setelah mengikuti kegiatan belajar mengajar.

3. Diadakan program remidi dan pengayaan bagi peserta didik setelah menganalisis penilaian. Remidi dilakukan kepada siswa yang belum menguasai suatu kompetensi dasar dan mengikuti proses pembelajaran lagi. Bagi siswa yang yang telah menguasai kompetensi dasar diberikan pengayaan dan boleh mempelajarai kompetensi dasar berikutnya

4. Penilaian dilakukan untuk menyeimbangkan berbagai aspek pembelajaran berupa kognitif, afektif, psikomotor dengan memakai berbagai model penilaian secara berkesinambungan.

5. Dalam sistem penilaian yang berkesinambungan, guru harus membuat keseluruhan hal terkait penilaian yang berupa kisi-kisi penilaian dan rancangan penilaian

6. Penilaian diterapkan dengan prinsip penilaian yang berkelanjutan, buktibukti yang otentik, akurat dan konsisten

7. Penilaian berdasarkan pada standar kompetensi, kompetensi dasar dan indikator, yang akan memberikangambaran tentang kompetensi yang telah dicapai oleh peserta didik .

Dalam pembelajaran, sistem penilaian disesuaikan dengan proses pengalaman belajar. Misalnya, jika KBM menggunakan pendekatan observasi lapangan, maka evaluasi harus diberikan baik pada proses maupun informasi yang dibutuhkan. Hasil evaluasi pembelajaran dapat memberikan umpan balik kepada pengajar/pendidik sebagai dasar untuk memperbaiki proses pembelajaran (Manab, 2015).

Kurikulum Tingkat Satuan Pendidikan (KTSP) mempunyai ciri yang paling menonjol, yaitu guru diberikan kebebasan/keluasan untuk merencanakan pembelajaran dengan menyesuaikan antara lingkungan, kondisi siswa dan sekolah. Hal ini dikarenakan Kemendikbud telah menetapkan Kerangka Dasar (KD), Standar Kompetensi Lulusan (SKL), Standar Kompetensi dan Kompetensi Dasar (SK-KD). Sebenarnya, KTSP memberikan peluang yang cukup luas untuk menunjukkan kreativitasnya kepada guru dan masing-masing sekolah sedangkan pemerintah menetapkan standar kurikulumnya. Guru dengan berbagai kreativitasnya diharapkan mampu mengkonsep dan menjalankan proses pembelajaran dengan baik (Asriati, n.d.).

Kurikulum 2013 hadir untuk memberikan tambahan dari berbagai kekurangan yang ada pada kurikulum sebelumnya. Adapun perubahan pada kurikulum 2013 meliputi, Perubahan kompetensi kelulusan, kedudukan mata pelajaran (isi), pendekatan, struktur kurikulum (mata pelajaran dan alokasi waktu perminggu) isi, proses pembelajaran, penilaian hasil belajar, dan ekstrakurikuler (Sumiyatun, 2017).

Dalam kurikulum 2013 penilaian menggunakan pedekatan autentik assesment. Penilaian autentik adalah penilaian secara keseluruhan, meliputi sikap, pengetahuan dan keterampilan. Untuk menciptakan penilaian yang baik, harus memperhatikan hal-hal berikut: a) penilaian digunakan untuk mengukur pencapaian kompetensi yaitu KD-KD pada KI-3 dan KI-4, b) berdasarkan pada kemampuan peserta didik setelah mengikuti proses pembelajaran c) sistem penilaian yang berkesinambungan d) menindaklanjuti perbaikan proses pembelajaran setelah menganalisis hasil penilaian e) pengalaman belajar peserta didik dalam proses pembelajaran menjadi acuan dari penilaian (Suyatmini, 2017). 
Dari uraian dan penjelasan tentang kurikulum KTSP dan Kurikulum 2013 didapat pemahaman bahwa pada dasarnya kurikulum dikembangkan memiliki maksud dan tujuan untuk 1) meningkatkan kualitas standar kompetensi lulusan, 2). Meningkatan mutu standar proses, dan 3). Meningkat kualitas penilaian, serta 4). Memberi peran dan posisi yang sama antara peran yang dimainkan oleh guru dan murid.

Ada perubahan yang mendasar adanya perubahan penerapan KTSP dengan Kurikulum tahun 2013, yakni dalam hal pendekatan pembelajaran. Melalui pendekatan scientific posisi dan peran guru di dalam proses pembelajaran lebih memposisikan diri sebagai fasilitator, mediator, dan motivator dengan lebih memberi peran aktif kepada peserta didik untuk belajar untuk mencapai tujuan belajarnya. Maksud dan tujuan yang lebih mendalam dari implementasi K13 sesuai pengalaman belajar yang digagas oleh Edgar Dale, bahwa peserta didik semakin diberi peran dalam proses pembelajaran, maka pencapaian tujuan belajar belajar (dengan lebih memiliki pemahaman dan daya ingat yang kuat sebagai hasil belajar akan lebih mudah diperoleh.

Berdasarkan hasil observasi dan wawancara yang dilakukan oleh peneliti, Diskursus implementasi Kurikulum Tingkat Satuan Pendidikan (KTSP) dan Kuirkulum tahun 2013 di lembagalembaga SLTA yang berada di bawah naungan Yayasan Pondok Pesantren Nurul Jadid, melahirkan aposteriori pengalaman belajar dan mengajar bagi guru. Beberapa aposteriori tersebut terungkap dari hasil observasi dan wawancara yang dilakukan, bahwa implementasi Kurikulum tahun 2013 dapat lebih mempermudah pencapaian tujuan belajar peserta didik melalui peran sebagai mediator, fasilitator, dan mediator. Sebagaimana disampaikan oleh Ibu Farhah, S. Pd. Pengampu materi pelajaran Sejarah Kebudayaan Islam (SKI) di MA Nurul Jadid tentang implementasi pendekatan Scientific "bahwa implementasi KTSP dalam pembelajaran lebih banyak menggunakan pendekatan yang berpusat pada guru, guru dituntut untuk menguasasi materi untuk ditarnsfromasikan kepada siswa guna mencapai tujuan belajar, dalam hal ini siswa cenderung pasif dan kesulitan dalam mencapai tujuan belajar dengan maksimal. Berbeda dengan implemntasi K13, ada peran yang hampir sama sebagai subjek dalam pembelajaran antara guru dan siswa. Pada dasarnya siswa yang belajar, guru memberi peran melalui pendekatan scientific. Dengan peran sebagai fasilitator, motivator dan mediator disamping pembimbing dan pengarah dalam kelas, kompetensi siswa lebih terasah dan pengukuran dan penilaian hasil belajar atau pencapai tujuan belajar lebih terukur dan lebih maksimal. Hal tersebut tidak ditemukan dalam implemntasi KTSP".

Dalam pembelajaran kurikulum 2013 siswa diajak untuk lebih berani dalam menyampaikan pendapatnya didepan orang lain. Hal ini bisa dilihat dari penyampaian Ibu Uswatun Hasanah pengampu materi pelajaran Bahasa Arab di MAN 1 Probolinggo terkait implementasi pendekatan saintifik. "Untuk pembelajaran bahasa arab saya sudah menerapkan pendekatan saintifik tersebut. Contohnya, saya memanggil 2 orang siswa untuk melakukan percakapan dengan menggunakan bahasa arab sesuai dengan yang ada dalam buku. Selanjutnya siswa disuruh mengartikan percakapan tersebut dan menanyakan terkait kosa kata yang belum diketahui maknanya kepada guru. Setelah semua siswa sudah mengartikan makna percakapan tersebut, siswa harus mengumpulkan hasil tugasnya. Kemudian siswa yang berani maju memeprsentasikan hasil tugasnya akan diberikan nilai tambahan". Hal positif yang juga didapat dari pendekatan saintifik, siswa diajak untuk menghormati pendapat orang lain, sebagaimana yang dilakukan oleh Ibu Yakutillah pengampu mata pelajaran matematika di SMA Nurul Jadid, siswa harus mengamati temannya ketika 
menjelaskan dipapan tulis. "Pertama, saya yang menjelaskan materi, siswa memperhatikan materi yang saya sampaikan dan ini termasuk pendekatan saintifik melalui mengamati. Setelah itu saya memberikan waktu kepada siswa untuk menanyakan hal yang tidak dan belum dimengerti. Kemudian setelah siswa telah memahami, saya menunjuk satu atau dua siswa untuk mencoba materi yang saya sampaikan. Setelah itu siswa yang sudah mengerjakan uji coba di papan tulis, harus menjelaskan kepada temannya". Pelaksanaan kurikulum 2013 juga masih ada sejumlah kekurangan, yaitu tidak memiliki pedoman penjurusan serta tidak merincikan pedoman kolaborasi kontekstual dan praktek. Hal ini akan membuat bingung pihak sekolah, khususnya guru yang menjadi fasilitator dalam proses pembelajaran, sehingga terkadang guru memang memakai kurikulum 2013 akan tetapi ketika proses pembelajaran menggunakan KTSP. Sebagaimana yang disampaikan oleh bu Nurul Laili pengampu mata pelajaran produktif di SMK Nurul Jadid "Dalam proses pembelajaran guru masih lebih banyak aktif karena dalam pembelajaran produktif guru lebih cenderung memahamkan terlebih dahulu kepada siswa terkait materi. Karena mata pelajaran produktif merupakan mata pelajaran yang tidak bisa mencari sumber belajar yang lain, jadi guru yang paling banyak berperan dalam proses pembelajaran. Dalam proses pembelajaran saya memadukan 2 kurikulum. Teorinya memang kurikulum 2013 akan tetapi prosesnya menggunakan KTSP”.

\section{PENUTUP}

Dari beberapa pembahasan diatas, dapat ditarik kesimpulan bahwasanya perubahan kurikulum memiliki maksud dan tujuan serta diarahkan untuk memperbaiki kurikulum sebelumnya. KTSP merupakan kurikulum yang dikembangkan berdasarkan potensi setiap daerah/sekolah, dalam hal ini pemerintah sangat memberikan keluasan kepada setiap sekolah untuk mengembangkan potensi sekolahnya untuk mencapai tujuan dan keinginan yang diharapkan. Dalam pembelajaran KTSP guru sangat berperan aktif dalam memahamkan peserta didik dan penilaiannya bertitik pada hasil pembelajaran, tugas guru lebih murni kepada pengajaran yakni mentransformasi pengetahuan kepada peserta didik. KTSP belum maksimal dalam menerapkan kata "pembelajaran" di dalam kelas. Kurikulum 2013 hadir dengan menggunakan pendekatan saintifik, yang meliputi mengamati, menanya, mencoba, menalar serta mengkomunikasikan. Dalam proses pembelajarannya, kurikulum 2013 lebih menitikberatkan pada keaktifan siswa (student centre) guru lebih membelajarkan siswa secara mandiri dengan pengawasan guru melalui penedekatan scientific. Tugas guru lebih ringan dengan tidak mendominasi kelas dengan ceramah guru dalam metode mengajar Hal ini dapat menjadikan siswa lebih aktif, kritis dan mandiri. berdasarkan observasi dan wawancara, peneliti menemukan jawaban bahwasanya lembaga pendidikan SLTA di lingkungan Pondok Pesantren Nurul Jadid telah menerapkan kurikulum 2013 dengan baik. Dimana pihak sekolah dan guru berupaya untuk keberhasilan kurikulum 2013 tersebut. Dalam proses pembelajaran guru sudah menggunakan pendekatan saintifik. Dimana dalam kegiatan tersebut siswa sudah berperan lebih aktif daripada guru. Tetapi masih ada beberapa mata pelajaran yang tidak menggunakan pendekatan saintifik, dikarenakan sulitnya mata pelajaran tersebut jika menggunakan pendekatan saintifik. Dari kendala tersebut, peneliti memberikan saran kepada setiap guru hendaknya mempunyai inovasi dan kreatifitas dalam proses pembelajaran agar menciptakan suasana belajar yang menyenangkan. Dari diskursus kurikulum 2013 \& KTSP dapat ditemukan aposteriori bahwasanya penerapan kurikulum 2013 lebih baik dari KTSP. Lembaga pendidikan yang ada di lingkungan Pondok Pesantren 
Nurul Jadid lebih setuju terhadap penerapan kurikulum 2013 di sekolah.

\section{DAFTAR PUSTAKA}

Alamsyah, H. A. \& A. amin. (2013). Pengembangan Kurikulum. (M. Amin, Ed.) (Cet ke 5). Surabaya: Kopertais Wilayah IV Surabaya.

Alinawati, M. (2013). Implementasi Kurikulum 2013 Pada Sekolah Menengah Kejuruan Di Bandung. Jurnal Edutech, 1(3), 343-360.

Arifin, Z. (2013). Konsep dan Model Pengembangan Kurikulum. (P. Latifah, Ed.) (Cet ketiga). Bandung: Rosdakarya.

Asriati, N. (n.d.). Implementasi KTSP dan Kendalanya (Antara Harapan dan Kenyataan). Jurnal Visi Ilmu Pendidikan, 243-256.

Baharun, H. (2017). Pengembangan Kurikulum; Teori \& Praktik. (Zamroni, Ed.) (Cet pertam). Yogyakarta: Pustaka Nurja.

Fadlillah, M. (2014). Implementasi Kurikulum 2013. Yogyakarta: ArRuzz Media.

Idi, A. (2014). Pengembangan Kurikulum; Teori dan Praktik. (Safarina, Ed.) (Cet 1). Jakarta: Rajawali Pers.

Islam, S. (2017). Karakteristik Pendidikan Karakter; MenjawabTantangan Multidimensional Melalui Implementasi Kurikulum 2013. Jurnal Edureligia, 01(01), 89-101.

Lalo, K. (2018). Menciptakan Generasi Milenial Berkarakter dengan Pendidikan Karakter guna Menyongsong Era Globalisasi. Jurnal Ilmu Kepolisian, 12(2), 72.

Machali, I. (2014). Kebijakan Perubahan Kurikulum 2013 dalam Menyongsong Indonesia Emas
Tahun 2045. Jurnal Pendidikan Islam, IIII(1), 2-25. https://doi.org/10.14421/jpi.2014.31. 71-94

Manab, A. (2015). Manajemen Kurikulum Pembelajaran di Madrasah. Yogyakarta: Kalimedia.

Mastur. (2017). Implementasi Kurikulum 2013 dalam Pelaksanaan Pembelajaran Di SMP. Jurnal Inovasi Teknologi Pendidikan, 4(1), 50-64.

Mulyasa. (2011). Kurikulum Tingkat Satuan Pendidikan. (Mukhlis, Ed.) (Cetakan ke). Bandung: PT Remaja Rosdakarya.

Nizar, S. (2013). Sejarah Sosial dan Dinamika Intelektual Pendidikan Islam di Nusantara. Jakarta: Kencana.

Otang Kurniawan, E. N. (2017). Penerapan Kurikulum 2013 dalam Meningkatkan Keterampilan, Sikap, dan Pengetahuan. Jurnal Primary Program Studi Pendidikan Guru Sekolah Dasar Fakultas Keguruan Dan Ilmu Pendidikan Universitas Riau, Vol 6(No 2), 389-396.

Sanjaya, W. (2008a). Kurikulum dan Pembelajaran: Teori dan Praktik pengembangan Kurikulum Tingkat Satuan Pendidikan (KTSP) (Edisi Pert). Jakarta: Kencana Prenada Media Group.

Sanjaya, W. (2008b). Perencanaan \& Desain Sistem Pembelajaran. Jakarta: Kencana.

Sufairoh. (2016). Pendekatan Saintifik \& Model Pembelajaran K-13. Jurnal Pendidikan Profesional, 5(3), 116125.

Sumiyatun, S. M. \&. (2017). Implementasi Kurikulum 2013 dalam Pembelajaran Sejarah di SMA 
Negeri 1 Metro. Jurnal Historia, 5(1), 45-54.

Supriyono. (2015). Studi Analisis Konsep Pengembangan Kurikulum 2013; Sebuah tantangan Bagi Pendidikan Islam. Jurnal Didaktika Islamika, 5(1), 109-125.

Sutjipto. (2016). The Importance of Training Curriculum 2013 for Teachers Pentingnya Pelatihan Kurikulum 2013 bagi Guru. Jurnal Pendidikan Dan Kebudayaan, 1(2), 236.

Suyatmini. (2017). Implementasi Kurikulum 2013 pada Pelaksanaan Pembelajaran Akuntansi di Sekolah Menengah Kejuruan. Jurnal Pendidikan Ilmu Sosial, 27(1), 60 68.

Syarwan, A. (2014). Problematika Kurikulum 2013 dan Kepemimpinan Instruksional Kepala Sekolah. Jurnal Pencerahan, 8(2), 98-108.

Syofiani, Y. M. dan. (2015). Pengaruh Penerapan Kurikulum 2013 Terhadap Pembentukan Karakter Siswa Sekolah Dasar Negeri 05 Percobaan Pintu Kabun Bukittinggi. Jurnal Gramatika Penelitian Bahasa Dan Sastra Indonesia, 1(2), 141152.

Waseso, H. P. (2018). Kurikulum 2013 Dalam Perspektif Teori pembelajaran Konstruktivis. Jurnal Ta'lim: Studi Pendidikan Islam, 1 (1), 59-72.

Widyastono, H. (2015). Pengembangan Kurikulum Di Era Otonomi Daerah dari Kurikulum 2004, 2006, ke Kurikulum 2013. (S. H. Hasan, Ed.) (Cet. 2). Jakarta: Bumi Aksara.

Yoserizal Bermawi, T. F. (2016). Penerapan Pendekatan Saintifik dalam Pembelajaran di Sekolah
Dasar Aceh Besar. Jurnal Pesona Dasar, 2(4), 63-71.

Zaini, H. (2013). Karakteristik Kurikulum 2013 dan Kurikulum Tingkat Satuan Pendidikan (KTSP). Jurnal Idaroh, 1(1), 15-31. 
Tarbiyah: Jurnal Ilmiah Kependidikan

Vol. 8 No. 2 Juli - Desember 2019 (101-116) 